\title{
Floral Composition and Timber Stock of Forest In The Samar Island Natural Park
}

\author{
Justino M. Quimio \\ Department of Forestry, College of Environment and Forest Science, Visayas State \\ University, Baybay City, Leyte 6521-A, Philippines
}

ABSTRACT

Samar Island Natural Park (SINP) is the most important biodiversity refuge Samar Island. This assessment characterized floral diversity status in SINP and provided recommendations on how such resources can be better managed and protected against destruction. Five watersheds, namely: Taft, Can-avid, Basey, Suribao and Catubig were sampled. In each watershed, a transect line with 25 plots spaced at $200 \mathrm{~m}$ interval was used in the survey. Plot size was $20 \mathrm{~m}$ x $20 \mathrm{~m}$. Trees $10 \mathrm{~cm}$ in diameter at breast height (DBH) and bigger were measured for stem diameter, merchantable height and tree height. This was for computation of timber volume. The species composition in 3 vegetative layers, such as tree layer, undergrowth and ground layer, was determined using the standard Braun-Blanquet methodology.

The forest stands in the five watersheds was dominated by dipterocarp species. Of the 212 timber tree species in the tree layer, 35 species had diameter of at least $60 \mathrm{~cm}$. Eighty-six percent of individual trees were dipterocarps, in 14 species. Shorea squamata and Shorea polysperma was the most frequent. Non-dipterocarp species dominated in number at the lower DBH range, particularly in the $10-20 \mathrm{~cm}$ and $21-40 \mathrm{~cm}$ DBH range. The forest of Samar still has high volume of commercial-size timber.

Forests in the 5 watersheds differed in species composition and structure. The absence of access roads to interior barangays contributed to the conservation of forests. The transport system, such as presence of access road and connecting transport facilities to the main roads had influence to the degree of poaching activities. Areas that had access only through motorboats in shallow river had lowest incidence of poaching.

Keywords: Natural park, Philippine flora, biodiversity

\section{INTRODUCTION}

The Department of Environment and Natural Resources (DENR) Administrative Order 25, series of 1992, serves as the implementing rules and regulations of the National Integrated Protected Area System (NIPAS)

Correspondence: J.M. Quimio Address: Department of Forestry, College of Environment and Forest Science, Visayas State University, Baybay City, Leyte 6521-A, Philippines Tel No.: +639954488535; Email: quimiojm@yahoo.com DOI: $10.32945 /$ atr3823.2016 
General Management Planning Strategy, which will guide the formulation of the general management plan for each protected area. Each protected area of the country is required to have a management plan prepared by three experts, one of which is on field inventory of resources within the area.

The Samar Island Natural Park (SINP) is located at the core of Samar Island and, as provided for by Presidential Proclamation 442, it measures 333,300 hectares and has a buffer zone of 124,500 hectares. It covers 8 major watersheds, which include 19 municipalities of Eastern Samar, 14 municipalities of Samar Province and 4 municipalities of Northern Samar. This should be the third time a floral inventory is conducted in the area. The first one was the preliminary floral inventory done by Quimio and Patindol (1999), a document used in support for the proposal to United Nations Development Program UNDP to provide funds for the Samar Island Biodiversity Project (SIBP). The second was the biological resources assessment conducted by SEAMEO-SEARCA (2004), being one of the major activity components during the implementation of the project and in consideration of converting the area to become the Samar Island Natural Park and inclusion to the Global Environmental Facility (GEF) through the (UNDP). This third one was on post-project biological resources assessment for the SIBP, which had been conducted again by Quimio and Patindol (2012). The assessment covered both flora and fauna, but due to space limitation, this paper would be only on flora.

The first two assessments were focused on measurement of flora on species diversity in the existing forests. The first one failed to do timber measurements due to time constraints. The second one was conducted by a group of botanists and assessments were concentrated to number of species, relative frequencies of species and the endemics and rare species in the area. This third one included measurements on timber size and timber volume and the assessment of threats to forest resources, together with the measurement of floral diversity and the degree of similarity in species composition among sampling sites. Baseline information on the structure and species composition of the timber components in sampled forest sites is important as benchmark data to detect change in terms of structural improvement, or even if there is degradation, in the future. It is generally agreed that structural diversity of forests is also associated to species diversity not only of flora but also of fauna. Besides, monitoring for change in structural diversity and degradation in forest is much easier to undertake than to monitoring of floral diversity at the species level. For the operations of the SINP, whose personnel are mostly foresters, protecting the forests in general would also mean protecting the biological diversity therein.

The general objective on the assessment of flora inside SINP was to establish baseline data on existing flora and assess the treats to biological diversity. The specific objectives include the following: 
1. To determine the floristic composition of forests;

2. To characterize the existing timber stock of forests;

3. To identify and assess potential threats to biodiversity; and

4. To provide bases for policy recommendation and inputs in updating the SINP management plan

\section{MATERIALS AND METHODS}

\section{The Study Area}

The Samar Island Natural Park has 8 major watersheds: Suribao, Canavid, Catubig, Taft, Basey, Dolores, Gandara and Pambujan. This study covered only the first five watersheds.

The SINP has abundant rainfall with mean annual rainfall of about $3,600 \mathrm{~mm}$. Climatic types II and IV prevail in the area. Type II is characterized by having no dry season, with pronounced maximum rainfall period in the months of December and January. Type IV has more or less even distribution of rainfall throughout the year, or without period with maximum rains. Within the protected area, only about $2 \%$ can be considered flat, $14 \%$ as undulating to flat and the rest is rolling to moderately steep and very steeply mountainous. The soil is clay loam to clay.

The geology is mostly Miocene to Holocene sedimentary rocks and sediments. Where the SINP is located, the sedimentary formation generally consists of basement rocks, sometimes with overlying clastic rocks or limestone. The area consists of an interior highland with marked accordant peaks and a surrounding limestone or karst terrain. The southern peninsula is made up of jungle-covered limestone ridge that appears to be a younger coral reef. The central highlands are principally of igneous complex intercalated with metamorphosed sedimentary rocks. With The presence of thick mantle of laterite soil, indicates that the igneous rocks have been subjected to intense mechanical and chemical weathering. A more complete physical characterization of the SINP area is presented in UNDP-GEF (2007).

\section{Data Collection}

One transect line each for Suribao Watershed, Can-avid Watershed, Catubig Watershed, Taft or Ulot Watershed and Basey Watershed had been laid for data collection. The transects were laid in Barangay San Rafael in Taft Watershed, Sitio Tula in Can-avid Watershed, Basey in Basey Watershed, Barangay Benowangan in Suribao Watershed and Las Navas in Catubig Watershed. Each transect had 25 sampling plots, with distance interval of 200 meters, to a total length of 5 kilometers. Following the Smithsonian Institute tradition on sampling of forests, the plot size used was $20 \mathrm{~m} \times 20 \mathrm{~m}$. This gave a total forests area of one hectare composite sample per watershed, or a total of 5 hectares for the 5 watersheds. 
Two sampling methodologies were applied during the collection of data in plots. These were: 1) for data on species and sizes of standing timber and 2) for floristic data on species, plot cover dominance of species and frequency of occurrence of species through Braun-Blanquet (1964) methodology.

\section{Tree Measurements}

The plots had the North-South and East-West directions on sides. Upon determination of the corners of the plot, trees standing within the plot were measured. At each tree, the species was first identified and then diameter at-breast height (DBH) was taken and recorded. Only trees with DBH of $10 \mathrm{~cm}$ and larger were taken for measurements. The determination of merchantable height ( $\mathrm{MH}$ ) and tree height $(\mathrm{TH})$ then followed. The $\mathrm{MH}$ and $\mathrm{TH}$ were determined based on estimates. The crew had undergone training exercises in estimating heights days before going into data collection.

Though trees smaller than $10 \mathrm{~cm}$ in diameter were not included in the measurements, they are not actually left out in the data collection particularly in view of assessing the totality of species diversity. The occurrence of wildlings, saplings or small trees and non-tree species especially those in the ground layer of forest stands were designed to be covered by the data collection under the Braun-Blanquet methodology.

\section{The Braun-Blanquet Methodology}

This methodology is based on $100 \%$ identification and listing of all species in the plots. At each plot, data collection was undertaken separately for each of the 3 canopy layers or vegetative stratifications. The vegetative strata used were: 1) ground layer, for plants of up to 2-m high; 2) understory, for plants whose leaf canopy reaches $2-\mathrm{m}$ to $7-\mathrm{m}$ high; and, 3) the tree layer, for all plants over 7-m in height.

At each layer data collection started with identification of all species present. After all the species had been listed, we returned to the uppermost part of the list of species. The plot cover dominance for each of the species in the list was estimated and recorded. The listing of species and the recording of their respective plot cover dominance were first done for the tree layer, followed by the undergrowth layer and then for the ground layer. The recording of the plot cover dominance scale for all species was based on Braun-Blanquet (1964) scale, as show in the table that follows below. For plants that can grow big and express canopy dominance, particularly the tree species in forests, percent plot cover was given importance over the number of individuals. For smaller plants, especially those not reaching $5 \%$ plot cover dominance, the number of individuals was also given importance. This is because for small plants, including the case of wildlings of potentially large tree species, abundance in terms of number can provide more meaningful interpretation than the degree of spread of their foliage. 


\begin{tabular}{cl} 
Scale & \multicolumn{1}{c}{ Plot Cover Dominance } \\
5 & $70-100 \%$ plot cover \\
4 & $50-75 \%$ plot cover \\
3 & $25-50 \%$ plot cover \\
$2 \mathrm{~A}$ & $15-15 \%$ plot cover \\
$2 \mathrm{~B}$ & $5-15 \%$ plot cover \\
$2 \mathrm{M}$ & $<\% 5$ plot cover, over 50 individuals \\
1 & $<5 \%$ plot cover, $6-50$ individuals \\
+ & $<5 \%$ plot cover, $3-5$ individuals \\
R & $<5 \%$ plot cover $1-2$ individuals only
\end{tabular}

\section{Data Presentation and Interpretation}

The Braun-Blanquet data were presented in a vegetation table which shows relative dominance of species in plots and across plots in the 5 transects, giving the range of spread or distribution of all species within and across the 5 watershed areas.

The degree of similarity in species composition among transects was presented using a table on Jaccard indices. Jaccard index was calculated using the formula below:

$$
J=\frac{c}{a+b-c}
$$

where: $\quad J=$ the Jaccard index

$\mathrm{a}=$ the number of species in the first population;

$\mathrm{b}=$ the number of species in the second population;

$\mathrm{c}=$ the number of species occurring in both populations.

The denominator in the above formula was the combined number of species that occurred in both populations. Thus, the Jaccard index is simply the decimal point ratio on number of species common to both populations over the total number of species that occurred in both populations. When the decimal is moved two places forward and multiplied by 100 , the result would be the percentage of species that occurred in common to both populations over the total number of species from both populations. 


\section{RESULTS AND DISCUSSION}

\section{A. Timber Stand Structure}

\section{Timber stock volume}

The 5 watersheds had an average of only 35 trees/ha, for trees with DBH of $10 \mathrm{~cm}$ and higher (Table 1). Large trees of up to over $120 \mathrm{~cm}$ were recorded but the greatest number was in $10 \mathrm{~cm} \mathrm{(61 \% )} \mathrm{to} 40 \mathrm{~cm}(25 \%)$ in DBH (Table 2 and Figure 1). The predominance of small diameter trees and very low number of large trees can be attributed to past logging operations. Apparently, however, the difference in number of large trees from one watershed to the other can be associated to still too visible damage by timber poaching. The comparative higher number of trees with above 60 cm DBH (Table 2) in Sitio Tula and Can-avid Watershed and in Barangay Las Navas in Catubig Watershed can be associated to observed much lower extraction of large trees. The transect in Las Navas was too remote from villages and in an area with critical peace and order situation.

The situation in Sitio Tula is entirely different and its implications should be given attention in SINP's conservation strategies. The transect was only 300 meter away from the village. The village is accessible only from the main road by a wooden canoe. Because the river is too shallow the canoe can accommodate only 2 passengers plus the pilot. Thus, it is not possible to transport lumber out of the area. Lumbering was only for onsite consumption. Most houses were wooden, large and 2-storey but old. There were no new houses for new families. Quite observable in the village was the absence of youth age bracket but many grade school children and the olds. After grade school, the children leave for high school, seek house help jobs and very rarely return to Tula to establish a family. People in Sitio Tula highly depend on remittances from Manila and in tapping the resins of apitong (Dipterocarpus grandiflorus). Claim to ownership of apitong trees redound to their conservation. The economic carrying capacity of forest resources in Sitio Tula and mode of transport seemed to be what put limit to population increase. With the dominance of large trees and good canopy cover, the undergrowth and ground plants in the forest of Sitio Tula was subdued by competition for light.

In Barangay San Rafael of Taft Watershed, the removal of large trees encouraged the regeneration of dense stand of pole-size trees. These are the ideal size for the axe in highly observable charcoal making at that time. The forests in Basey Watershed and in Barangay Benowangan of Suribao Watershed had much reduced number of large trees but regeneration should be given the chance to compensate for the current rate of extraction. 
Past removal of medium-size and large trees in Benowangan gave it the lowest timber volume but, as a consequence, this also opened-up the undergrowth to sun light which encouraged the growth of thick thicket of saplings and pole-size trees (Table 3 ).

The average timber stock in 5 watersheds was only 1,400 cu.m/ha, very much low to justify commercial logging operations. Tula and Las Navas had the highest standing timber volume of 1,782 cu.m/ha and 2,304 cu.m/ha, respectively. These same two watersheds also got the highest basal area of 81.7 and $84.7 \mathrm{sq} \mathrm{m} / \mathrm{ha}$, respectively.

The predominance of small diameter trees resulted to low average of $26.61 \mathrm{~cm}$ in DBH Table 1), though there were trees with recorded DBH of up to over $120 \mathrm{~cm}$ (Table 2). The average height of trees in 5 watersheds was $20.5 \mathrm{~m}$ but few trees particularly those growing in foot-slopes and valley bottoms were estimated to reach over 60 meters in height (Figure 2).

Table 1. Totals and plot averages in tree measurements in 5 transects, for trees $10 \mathrm{~cm}$ in $\mathrm{DBH}$ and bigger. $\mathrm{DBH}=$ diameter at-breast height; $\mathrm{MH}=$ merchantable height; $\mathrm{BA}=$ basal area; $\mathrm{VOL}=$ timber volume; $\mathrm{TH}=$ tree height

\begin{tabular}{|c|c|c|c|c|c|c|c|}
\hline Watershed & Factor & $\begin{array}{c}\text { No. of } \\
\text { Individuals/plot }\end{array}$ & $\begin{array}{c}\mathrm{DBH}, \\
\mathrm{cm}\end{array}$ & $\begin{array}{c}\mathrm{MH}, \\
\mathrm{m}\end{array}$ & $\begin{array}{c}\text { BA, sq } \\
\text { m }\end{array}$ & $\begin{array}{c}\text { VOL, cu } \\
\text { m }\end{array}$ & $\mathrm{TH}, \mathrm{m}$ \\
\hline Taft & Average & 43.64 & 22.41 & 10.63 & 2.686 & 40.98 & 15.74 \\
\hline Can-avid & Average & 40.32 & 25.39 & 13.92 & 3.414 & 74.70 & 21.21 \\
\hline Basey & Average & 30.88 & 27.19 & 14.65 & 2.312 & 45.65 & 22.29 \\
\hline Suribao & Average & 37.96 & 22.49 & 12.34 & 2.147 & 33.96 & 18.40 \\
\hline Catubig & Average & 22.60 & 35.56 & 16.90 & 3.505 & 94.95 & 24.84 \\
\hline \multicolumn{2}{|c|}{ Average } & 35.08 & 26.61 & 13.69 & 2.813 & 58.05 & 20.50 \\
\hline & & Stems/ha & & & Sq.m/ha & Cu.m/ha & \\
\hline Taft & Total & 1,091 & - & - & 65.483 & 1,002 & - \\
\hline Can-avid & Total & 1,008 & - & - & 81.730 & 1,782 & - \\
\hline Basey & Total & 772 & - & - & 55.363 & 1,101 & - \\
\hline Suribao & Total & 949 & - & - & 52.017 & 830 & - \\
\hline Catubig & Total & 565 & - & - & 84.698 & 2,304 & - \\
\hline \multicolumn{2}{|c|}{ Average } & 877 & & & 67.86 & 1,404 & \\
\hline
\end{tabular}

Table 2. Frequency distribution of trees by diameter range, in $\mathrm{cm}$

\begin{tabular}{|c|c|c|c|c|c|c|c|c|}
\hline $\begin{array}{c}\text { Transect } \\
\text { Site } \\
\end{array}$ & $10-20$ & $21-40$ & $41-60$ & $\begin{array}{l}61- \\
80 \\
\end{array}$ & $\begin{array}{l}81- \\
100 \\
\end{array}$ & $\begin{array}{l}101- \\
120 \\
\end{array}$ & $>120$ & Total \\
\hline A. & \multicolumn{8}{|c|}{ Based on in number of trees transects. } \\
\hline Taft & 844 & 103 & 67 & 13 & 12 & 7 & 5 & 1,051 \\
\hline Can-avid & 542 & 317 & 78 & 21 & 10 & 11 & 9 & 988 \\
\hline Basey & 351 & 274 & 99 & 17 & 5 & 2 & & 748 \\
\hline Suribao & 631 & 185 & 57 & 11 & 9 & 2 & 2 & 897 \\
\hline Catubig & 216 & 193 & 65 & 40 & 21 & 9 & 12 & 556 \\
\hline Total & 2584 & 1072 & 366 & 102 & 57 & 31 & 28 & 4,240 \\
\hline \multicolumn{9}{|c|}{ B. Based on percentage of transect total. $218 / 4240=5.45 \%$} \\
\hline Taft & 80.30 & 9.80 & 6.37 & 1.24 & 1.14 & 0.67 & 0.48 & 100 \\
\hline Can-avid & 54.86 & 32.08 & 7.89 & 2.12 & 1.01 & 1.11 & 0.91 & 100 \\
\hline Basey & 46.92 & 36.63 & 13.24 & 2.27 & 0.67 & 0.27 & - & 100 \\
\hline Suribao & 70.34 & 20.62 & 6.35 & 1.23 & 1.00 & 0.22 & 0.22 & 100 \\
\hline Catubig & 38.85 & 34.71 & 11.69 & 7.19 & 3.78 & 1.62 & 2.16 & 100 \\
\hline Total & 60.94 & 25.28 & 8.63 & 2.40 & 1.34 & 0.73 & 0.66 & 100 \\
\hline
\end{tabular}




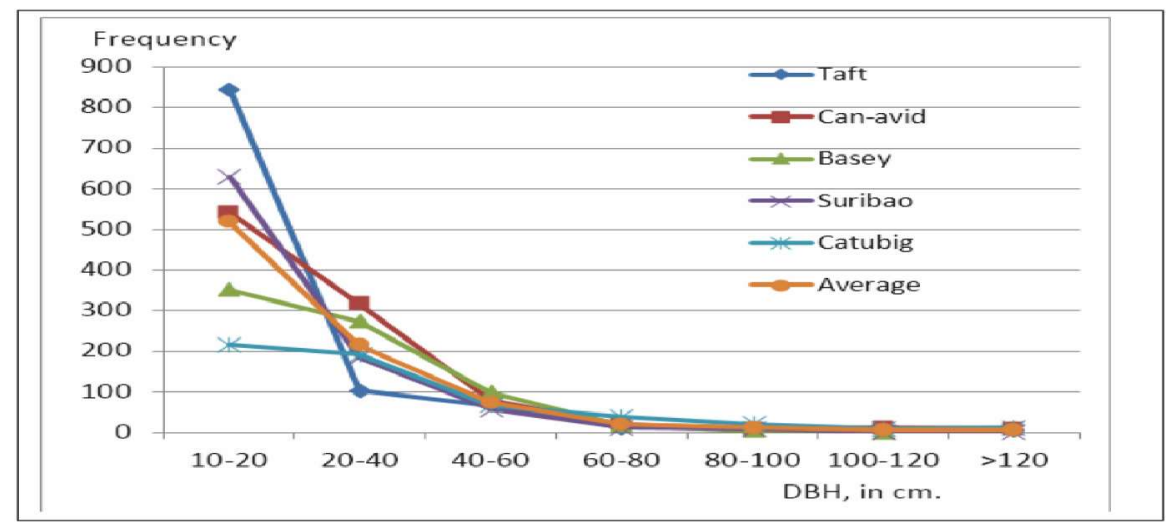

Figure 1. Frequency of trees per DBH bracket in the five watersheds, which is indicative of removal of large timber in past logging and timber poaching

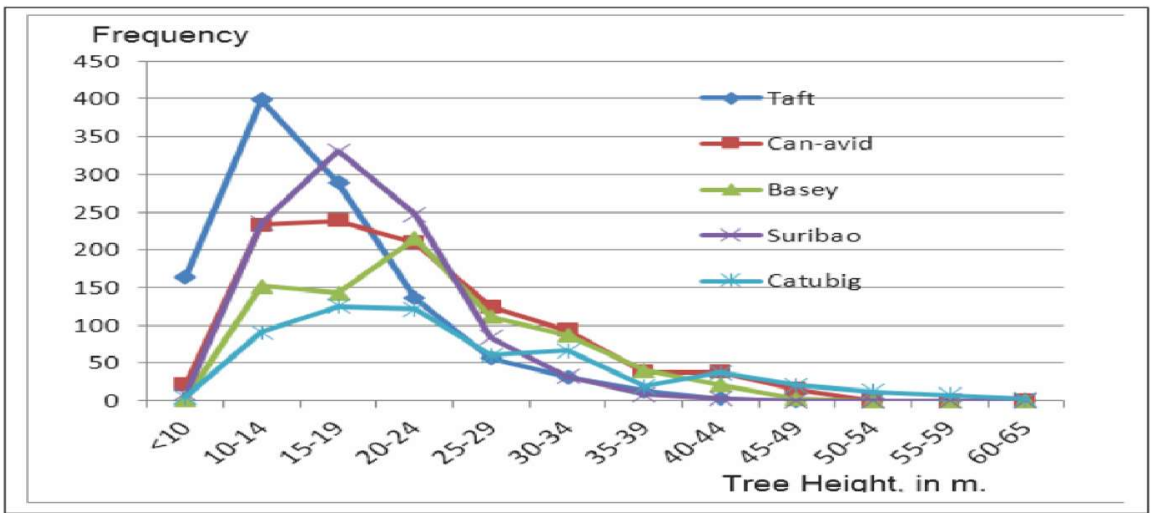

Figure 2. Frequency on tree height in the five watersheds, with central tendency at 10-30 m height range, though there are still some large trees

Table 3. Average plot canopy cover in the 3 vegetative strata, in percent

\begin{tabular}{lccccc}
\hline Transect Site & $\begin{array}{c}\text { Plot, All } \\
\text { Layers }\end{array}$ & Tree Layer & $\begin{array}{c}\text { Undergrowth } \\
\text { Layer }\end{array}$ & $\begin{array}{c}\text { Ground } \\
\text { Layer }\end{array}$ & $\begin{array}{c}\text { Slope, } \\
\text { degrees }\end{array}$ \\
\hline Taft & 79.8 & 34.6 & 23.52 & 34.2 & 39.6 \\
Can-avid & 82.4 & 64.4 & 31.0 & 29.8 & 21.8 \\
Basey & 70.2 & 52.0 & 37.0 & 31.0 & 16.1 \\
Suribao & 73.8 & 55.4 & 36.2 & 31.6 & 19.4 \\
Catubig & 81.5 & 61.4 & 22.4 & 22.6 & 18.6 \\
\hline
\end{tabular}

\section{Species of standing timber in watersheds}

Among the trees that reached the commercial size of $60 \mathrm{~cm} \mathrm{DBH}$ and larger, 35 species were recorded (Table 4). Ten species of the family Dipterocarpaceae were the most frequent, which indicated that forest in SINP is truly a dipterocarp forest. These were Shorea polysperma, Shorea squamata, Shorea almon, Shorea astylosa, Parashorea plicata, Shorea philippinensis, Hopea malibato, Dipterocarpus grandiflorus, Dipterocarpus validus and Hopea foxworthyi. Again, Can-avid and Catubig 
Watersheds had the highest number of large trees.

The range of occurrence of timber species, including those in the smaller DBH brackets, can be better seen in Table 5. Fourteen (14) dipterocarp species were listed, though only ten of them was recorded having DBH above $60 \mathrm{~cm}$. Seven (7) dipterocarp species were found widespread by being present in the 5 watersheds. These were Shorea squamata, Shorea gisok, Shorea polysperma, Hopea foxworthyi, Hopea malibato, Shorea almon and Shorea astylosa. The other 7 dipterocarp species, such as the Dipterocarpus grandiflorus, Parashorea plicata, Shorea philippinensis, Shorea negrosensis, Dipterocarpus gracilis, Anisopthera thurifera and Dipterocarpus validus showed confined range of occurrence by being present in one or two watersheds but absent in other watersheds. There were 30 non-dipterocarp trees that showed high constancy of occurrence in the 5 watersheds, thus, can also be considered frequent and widespread timber species in SINP. These species were Blumeodendron philippinense, Pouteria velutina, Myristica philippinensis, Vitex quinata, Calophyllum blancoi, Lithocarpus llanosii, Canarium hirsutum, Myristica laxiflora, Palaquium luzoniense, Radermachera pinnata, Reinwardiodendron celebicum, Myrica javanica, Polyalthia oblongifolia, Jossinia tulanan, Neotrewia cumingii, Garcinia oligophlebia, Memecylon sessilifolium, Strombosia philippinensis, Chisocheton cumingianus, Croton consanguineus, Timonius appendiculatus, Gnetum gnemon, Dillenia philippinensis, Elaeocarpus leytensis, Litsea albayana, Nephelium mutabile, Sapium luzonicum, Wrightia laniti, Syzygium striatulum and Garcinia venolusa.

The same confined occurrence in non-dipterocarp species, particularly almaciga (Agathis philippinensis), indicated that each of the 5 watersheds contains unique species composition. Moreover, Table 5 shows that there were species recorded as occurring in only one watershed and not in others. Confined occurrences of species rendered the forests in all 5 watersheds to be important in the conservation of the total diversity in SINP area. The Jaccard indices on similarity in composition of timber species in forests of the 5 watersheds are shown in Table 6. The Jaccard index ranged from 0.448 to 0.581 , to an average of 0.528 . This indicated that per pair of watersheds, only half the species of two watersheds are common to both. The need to protect each of the watersheds can be further enlightened if conservation of the associated dependent non-timber plants and fauna would be considered. The tapping of resins from apitong and almaciga, both shown here as confined to Taft and Can-avid Watersheds, respectively (Table 4), had been also considered an important factor for local communities to have interest in preserving the integrity their nearby forests. 
Table 4. Frequency of species in trees $60 \mathrm{~cm}$ DBH or bigger, by transect or watershed

\begin{tabular}{|c|c|c|c|c|c|c|c|}
\hline LOCAL NAME & LATIN NAME & Taft & $\begin{array}{l}\text { Can- } \\
\text { avid }\end{array}$ & $\begin{array}{l}\text { Ba- } \\
\text { sey }\end{array}$ & $\begin{array}{l}\text { Suri } \\
\text {-bao }\end{array}$ & $\begin{array}{l}\text { Catu } \\
\text {-big }\end{array}$ & Total \\
\hline Tangile & Shorea polysperma & 13 & 7 & 8 & 9 & 14 & 52 \\
\hline Mayapis & Shorea squamata & 6 & 8 & 13 & & 27 & 54 \\
\hline Almon & Shorea almon & 2 & 1 & & & 6 & 9 \\
\hline Yakal & Shorea astylosa & 2 & 1 & & & 5 & 8 \\
\hline Bagtikan & Parashorea plicata & 2 & & & & 22 & 24 \\
\hline mangasinoro & Shorea philippinensis & 8 & & & & & 8 \\
\hline Yakal-kaliot & Hopea malibato & 1 & & & & & 1 \\
\hline Apitong & Dipterocarpus grandiflorus & & 33 & & & 2 & 35 \\
\hline Hagakhak & Dipterocarpus validus & & & & & 1 & 1 \\
\hline Dalingdingan & Hopea foxworthyi & & & 1 & 1 & & 2 \\
\hline Nato & Palaquium luzoniense & & 1 & 1 & & 1 & 3 \\
\hline Bansalagin & Mimusops parviflora & 2 & & 2 & 3 & & 7 \\
\hline Tiga & Tristania micrantha & 2 & & 3 & 1 & & 6 \\
\hline Uakatan & Pouteria velutina & 1 & & 2 & 1 & & 4 \\
\hline Malaruhat sapa & Syzygium striatulum & 1 & & & 3 & 1 & 5 \\
\hline Salngan & Blumeodendron philippinese & 1 & & & & & 1 \\
\hline Almaciga & Agathis philippinensis & 4 & & & & & 4 \\
\hline Damol & Hydnocarpus subfalcata & 1 & & & & & 1 \\
\hline Ulaian & Lithocarpus llanosii & & 1 & & & & 1 \\
\hline Dungon & Tarrieta sylvatica & & 1 & & & & 1 \\
\hline Lumangog & Antirhea livida & & & 2 & & & 2 \\
\hline Hindang & Myrica javanica & & & 1 & & & 1 \\
\hline Bahai & Ormosia calavensis & & & 1 & & & 1 \\
\hline Patsaragon & Syzygium crassibracteatum & & & & 3 & & 3 \\
\hline Tabau & Lumnitzera littorea & & & & 1 & & 1 \\
\hline Dita & Alstonia scholaris & & & & 1 & & 1 \\
\hline Banaybanay & Radermachera pinnata & & & & 1 & & 1 \\
\hline Malakamanga & Reinwardiodendron celebicum & & & & 1 & & 1 \\
\hline Balau & Vaccinium perrigidum & & & & 1 & & 1 \\
\hline Toog & Petersianthus quadrilatus & & & & & 2 & 2 \\
\hline Milipili & Canarium hirsutum & & & & & 1 & 1 \\
\hline Bunsilak & Elaeocarpus leytensis & & & & & 1 & 1 \\
\hline malugai & Pometia pinnata & & & & & 1 & 1 \\
\hline Balakt gubat & Sapium luzonicum & & & & & 1 & 1 \\
\hline & Total & 46 & 53 & 34 & 24 & 85 & 242 \\
\hline
\end{tabular}

Table 5. Frequency of individuals on timber species in the 5 watersheds, for trees with DBH of $10 \mathrm{~cm}$ and larger. SINP, 2012

\begin{tabular}{|l|l|c|c|c|c|c|c|}
\hline Common Name & \multicolumn{1}{|c|}{ Latin Name } & Taft & $\begin{array}{c}\text { Can- } \\
\text { avid }\end{array}$ & $\begin{array}{c}\text { Ba- } \\
\text { sey }\end{array}$ & $\begin{array}{c}\text { Suri } \\
\text {-bao }\end{array}$ & $\begin{array}{c}\text { Catu- } \\
\text { big }\end{array}$ & Total \\
\hline Mayapis & Shorea squamata & 59 & 92 & 79 & 8 & 77 & 315 \\
\hline Yakal-gisok & Shorea gisok & 16 & 46 & 34 & 11 & 16 & 123 \\
\hline Tangile & Shorea polysperma & 63 & 70 & 33 & 40 & 21 & 227 \\
\hline Dalingdingan & Hopea foxworthyi & 37 & 27 & 38 & 29 & 1 & 132 \\
\hline Yakal-kaliot & Hopea malibato & 35 & 35 & 14 & 34 & 2 & 120 \\
\hline Almon & Shorea almon & 22 & 32 & 15 & 1 & 14 & 84 \\
\hline Yakal & Shorea astylosa & 26 & 9 & 8 & 4 & 10 & 47 \\
\hline
\end{tabular}


Table 5. Continuation

\begin{tabular}{|c|c|c|c|c|c|c|c|}
\hline Common Name & Latin Name & $\begin{array}{c}\text { Taf } \\
\mathrm{t}\end{array}$ & $\begin{array}{l}\text { Can- } \\
\text { avid }\end{array}$ & $\begin{array}{l}\text { Ba- } \\
\text { sey }\end{array}$ & $\begin{array}{c}\text { Suri- } \\
\text { bao }\end{array}$ & $\begin{array}{l}\text { Catu } \\
\text {-big }\end{array}$ & Total \\
\hline Salngan & Blumeodendron philippinense & 93 & 78 & 35 & 20 & 22 & 248 \\
\hline Uakatan & Pouteria velutina & 24 & 21 & 59 & 64 & 1 & 169 \\
\hline Duguan & Myristica philippinensis & 59 & 35 & 16 & 25 & 15 & 150 \\
\hline Kalipapa & Vitex quinata & 77 & 34 & 17 & 18 & 3 & 149 \\
\hline Bitanghol & Calophyllumblancoi & 32 & 40 & 24 & 21 & 2 & 119 \\
\hline Ulaian & Lithocarpus Ilanosii & 28 & 17 & 15 & 32 & 4 & 96 \\
\hline Milipili & Canariumhirsutum & 30 & 14 & 14 & 19 & 16 & 93 \\
\hline Duguan-malabai & Myristica laxiflora & 18 & 24 & 34 & 7 & 5 & 88 \\
\hline Nato & Palaquiumluzoniense & 17 & 13 & 7 & 25 & 26 & 88 \\
\hline Banaybanay & Radermachera pinnata & 33 & 4 & 18 & 5 & 1 & 61 \\
\hline malakamanga & Reinwardiodendron celebicum & 11 & 9 & 10 & 20 & 4 & 54 \\
\hline Hindang & Myrica javanica & 7 & 6 & 3 & 24 & 3 & 43 \\
\hline Lapnisan & Polyalthia oblongofolia & 10 & 6 & 7 & 9 & 10 & 42 \\
\hline Tulanan & Jossinia tulanan & 7 & 3 & 11 & 15 & 4 & 40 \\
\hline Apanang & Neotrewia cumingii & 3 & 1 & 10 & 1 & 22 & 37 \\
\hline Diis & Garcinia oligophlebia & 9 & 10 & 7 & 10 & 1 & 37 \\
\hline Babahian & Memecylon sissilifolium & 4 & 7 & 10 & 7 & 2 & 30 \\
\hline Tamayuan & Strombosia philippinensis & 8 & 8 & 1 & 1 & 9 & 27 \\
\hline Balukanag & Chisocheton cumingianus & 10 & 1 & 2 & 1 & 4 & 18 \\
\hline Malatuba & Croton consanguineus & 9 & 6 & 13 & 18 & & 46 \\
\hline Upong-upong & Timonius appendiculatus & 18 & 16 & 8 & 4 & & 46 \\
\hline Bago & Gnetumgnemon & 7 & 2 & 1 & 4 & & 14 \\
\hline Katmon & Dillenia philippinensis & 8 & 7 & 3 & & 3 & 21 \\
\hline Bunsilak & Elaeocarpus leytensis & 19 & 15 & 3 & & 4 & 41 \\
\hline Arahan & Litsea albayana & 10 & 6 & & 6 & 3 & 25 \\
\hline Kapulasan & Nepheliummutabile & 2 & 1 & & 6 & 6 & 15 \\
\hline Balakat gubat & Sapiumluzonicum & 31 & 24 & & 3 & 33 & 91 \\
\hline Lanete & Wrightialaniti & 7 & 2 & & 15 & 4 & 28 \\
\hline Malaruhat-sapa & Syzygiumstriatulum & & 63 & 25 & 65 & 24 & 177 \\
\hline Gatasan & Garcinia venolusa & & 3 & 2 & 1 & 1 & 7 \\
\hline Bansalagin & Mimusops parviflora & 5 & & 2 & 9 & 2 & 18 \\
\hline Gapas-gapas & Camptostemon philippinense & 5 & & 5 & 4 & 1 & 15 \\
\hline Kalingag & Cinnamomummercadoi & 1 & & 1 & 9 & 1 & 12 \\
\hline Salak & Elaeocarpus octopetalus & 1 & & 3 & 1 & 1 & 6 \\
\hline Almaciga & Agathis philippinensis & 5 & 2 & 4 & & & 11 \\
\hline Kamagong-bundok & Diospyros montana & 2 & 5 & 4 & & & 11 \\
\hline Apitong & Dipterocarpus grandiflorus & 1 & 144 & & 4 & & 149 \\
\hline Tiga & Tristania micrantha & 14 & 6 & & 1 & & 21 \\
\hline Sudiang & Ctenolophon philippinensis & 3 & 1 & & 6 & & 10 \\
\hline Marang & Litsea perrottetii & 1 & 1 & & 1 & & 3 \\
\hline Bubunau & Aglaia mirandae & 2 & 1 & & 1 & & 4 \\
\hline Kamagong & Diospyros philippinensis & 6 & 1 & & & 1 & 8 \\
\hline Bagilumbang & Aleurites trisperma & 1 & 1 & & & 1 & 3 \\
\hline Malatambis & Syzygiumhutchinsonii & & 1 & 3 & 37 & & 41 \\
\hline Dungon & Tarrieta sylvatica & & 2 & 3 & 10 & & 15 \\
\hline Lamio & Dracontomelon edule & & 2 & 1 & 4 & & 7 \\
\hline Sasalit & Teijsmanniodendron ahernianum & & 1 & 6 & & 5 & 12 \\
\hline Malasantol & Sandoricumvidalii & & 3 & 2 & & 3 & 8 \\
\hline Salingkugi & Albizia saponaria & 1 & & 1 & & 6 & 8 \\
\hline Damol & Hydnocarpus subfalcata & 5 & & 1 & & 9 & 15 \\
\hline
\end{tabular}


Table 5. Continuation

\begin{tabular}{|c|c|c|c|c|c|c|c|}
\hline Common Name & Latin Name & Taft & $\begin{array}{l}\text { Can- } \\
\text { avid }\end{array}$ & $\begin{array}{l}\text { Ba- } \\
\text { sey }\end{array}$ & $\begin{array}{l}\text { Suri } \\
\text {-bao }\end{array}$ & $\begin{array}{c}\text { Catu } \\
\text {-big }\end{array}$ & Total \\
\hline Madbad & Zantoxylum diabolicum & 1 & & 9 & 3 & & 13 \\
\hline Baganito & Diospyros bulusanensis & & & 3 & 1 & 4 & 8 \\
\hline Bagtikan & Parashorea plicata & 7 & & & 3 & 54 & 64 \\
\hline Patsaragon & Syzygium crassibracteatum & 4 & & & 21 & 1 & 26 \\
\hline Aunasin & Ardisia pyramidalis & 1 & & & 1 & 1 & 3 \\
\hline Malakauayan & Podocarpus philippinensis & 2 & 1 & & & & 3 \\
\hline Hindang & Myrica javanica & 1 & 1 & & & & 2 \\
\hline Balatbuaia & Fagraea racemosa & 1 & & 1 & & & 2 \\
\hline Hambabalud & Neonauclea formicaria & 1 & & 1 & & & 2 \\
\hline Bahai & Ormosia calavensis & & & 10 & 1 & & 11 \\
\hline Lumangog & Antirhea livida & & & 5 & & 1 & 6 \\
\hline Maglimokon & Urophyllum leytense & 1 & & & & 5 & 6 \\
\hline Palosapis & Anisoptera thurifera & 3 & & & 1 & & 4 \\
\hline Tulo & Alphitonia philippinensis & 2 & & & 1 & & 3 \\
\hline Manggasinoro & Shorea philippinensis & 15 & & & & & 15 \\
\hline Bunud & Knema mindanensis & 11 & & & & & 11 \\
\hline Malasapsap & Ailanthus integrifolia & 7 & & & & & 7 \\
\hline Piling liitan & Canarium luzonicum & 2 & & & & & 2 \\
\hline Ficus & Ficus sp. & 2 & & & & & 2 \\
\hline Lanipga & Toona philippinensis & 2 & & & & & 2 \\
\hline Anislag & Securinega flexiousa & 1 & & & & & 1 \\
\hline Red lauan & Shorea negrosensis & 1 & & & & & 1 \\
\hline Malabanaba & Syzygium banaba & 1 & & & & & 1 \\
\hline Samar yagau & Homalium samarense & 1 & & & & & 1 \\
\hline Tindalo & Afzelia rhomboidea & & 1 & & & & 1 \\
\hline Tikoko & Teijsmanniodendron pteropodium & & & 45 & & & 45 \\
\hline Kubi & Artocarpus nitida & & & 3 & & & 3 \\
\hline Pili & Canarium ovatum & & & 2 & & & 2 \\
\hline Panau & Dipterocarpus gracilis & & & 1 & & & 1 \\
\hline Dao & Dracontomelon dao & & & 1 & & & 1 \\
\hline Balau & Vaccinium perrigidum & & & & 61 & & 61 \\
\hline Atipan & Evodia sessilifiliola & & & & 20 & & 20 \\
\hline Burak & Cyathocalyx apoensis & & & & 10 & & 10 \\
\hline Bobotan & Tricospermum discolor & & & & 8 & & 8 \\
\hline Bagodilau & Neonauclea puberula & & & & 6 & & 6 \\
\hline Dita & Alstonia scholaris & & & & 5 & & 5 \\
\hline Kulatingan & Pterospermum obliquum & & & & 5 & & 5 \\
\hline Bakawan gubat & Caralla brachiata & & & & 3 & & 4 \\
\hline Dila-dila & Cynometra inequifolia & & & & 2 & & 2 \\
\hline Tarungatau & Evodia arborea & & & & 2 & & 2 \\
\hline Malanangka & Parartocarpus papuanus & & & & 1 & & 1 \\
\hline Malaigit & Cryptocarya oligocarpa & & & & 1 & & 1 \\
\hline Lipote & Syzygium polycephaloides & & & & 1 & & 1 \\
\hline Kurong & Claozylon pubescens & & & & & 16 & 16 \\
\hline Hagakhak & Dipterocarpus validus & & & & & 10 & 10 \\
\hline Bagna & Glochidion triandrum & & & & & 4 & 4 \\
\hline Toog & Petersianthus quadrilatus & & & & & 3 & 3 \\
\hline Narra & Pterocarpus indicus & & & & & 3 & 3 \\
\hline Paluai & Greeniopsis multiflora & & & & & 2 & 2 \\
\hline Pipi & Actinodaphne dolichophylla & & & & & 1 & 1 \\
\hline Fireball & Calliandra haematocephala & & & & & 1 & 1 \\
\hline Malugai & Pometia pinnata & & & & & 1 & 1 \\
\hline Ligas & Semecarpus cuneiformis & & & & & 1 & 1 \\
\hline Sambulauan & Syzygium albayense & & & & & 1 & 1 \\
\hline Banuyo & Wallaceodendron celebicum & & & & & 1 & 1 \\
\hline & $\begin{array}{c}\text { Total } \\
\end{array}$ & 967 & 961 & 693 & 818 & 510 & 3,949 \\
\hline
\end{tabular}


Table 6. Jaccard similarity indices among transects. Figures above the blanks on the diagonal were Jaccard indices and those below indicate the number of species occurring in both transects over the total number of species in two transects being compared. Ave = 0.528 . Range $=0.448-0.581$

\begin{tabular}{lcccccc}
\hline \multicolumn{1}{c}{ Watershed } & Taft & $\begin{array}{c}\text { Can- } \\
\text { avid }\end{array}$ & Basey & Suribao & Catubig & $\begin{array}{c}\text { No. of } \\
\text { Species }\end{array}$ \\
\hline Taft & & 0.581 & 0.448 & 0.558 & 0.472 & 71 \\
Can-avid & $46 / 78$ & & 0.555 & 0.573 & 0.513 & 50 \\
Basey & $42 / 86$ & $40 / 72$ & & 0.519 & 0.563 & 57 \\
Suribao & $48 / 86$ & $43 / 75$ & $41 / 79$ & & 0.500 & 67 \\
Catubig & $42 / 89$ & $38 / 74$ & $40 / 71$ & $40 / 80$ & & 63 \\
\hline Total of species & 71 & 50 & 57 & 67 & 63 & 112 \\
\hline
\end{tabular}

\section{B. Species Composition}

Vegetation data in the 125 plots, at 400 -sq.m/ plot, taken in the 5 watersheds are shown in the vegetation table (Table 7 in Appendix). The whole inventory of species had recorded 308 species in the 5 watersheds, 260 were tree species and 48 were non-tree species. More non-tree species could have been listed but the difficulty to complete the identification, particularly for herbs, ferns and lianas, had been a limitation. The 308 species belong to 72 families and 181 genera. The vegetation table also showed the site range of species, such as the widespread species that occurred in most of the watersheds and the species with more confined distribution. By mere inspection of the vegetation table, it was quite clear that not only trees but also under-story and ground plants tend to have confined distribution in the watersheds.

\section{CONCLUSION AND RECOMMENDATION}

Based on the findings, the following conclusions and recommendations are forwarded:

1. The forests in SINP watersheds are dipterocarp forest with very high floral diversity. The species of the canopy layer has the highest contribution to overall diversity as compared to undergrowth and ground layer plants. This suggests the importance of protecting the forest from structural degradation.

2. The watersheds contain widespread species that are common to all. There are species, both timber and non-timber, that haveconfined distribution to certain watersheds. The occurrence of certain groups of species in only one of the watersheds indicates that forests in each of the watersheds are important to maintain the total floral diversity in the SINP. 
Floral Composition and Timber Stock of Forest In Samar Island Natural Park

3. Timber volume in SINP remains high but below the level that would justify commercial logging operations. The presence of many big trees has been shown to be important to the maintenance of diversity in the watersheds. Control of timber poaching in the area should be always desirable.

4. Local people can contribute to the protection of forest when they can derive economic benefits from it. Utilization of non-timber forest products, such as resin from almaciga in Taft and balau from apitong in Can-avid Watersheds may be encouraged. The species composition of areas cleared by charcoal making can not return through natural regeneration even in 100 years. Charcoal making in Taft should be stopped.

5. Possibilities for transport of sawn timber are associated with rate of timber poaching. Most interior barangays have no road connection and mobility depends on the feeder river. Deeper river water allows bigger boats and sale of lumber to downstream. communities. In fact, the transport limitation from interior barangays and the rugged terrain should have left this part of Samar Island to remain still forested. Therefore, road development plans particularly by the local government units should always be required to secure environmental compliance certificate from the DENR.

6. The study was able to establish benchmark data on timber structure and species composition of the 5 watersheds covered. A study with similar methodology also should be undertaken for the 3 other watersheds, such as the Dolores, Gandara and Pambujan Watersheds. This is to have a complete picture of the total floral diversity and forest structure in the entire SINP.

\section{ACKNOWLEDGMENT}

Word of appreciation for the funding provided by the UNDP-GEF in the conduct of the SIBP post-project biological resource assessment and to the courtesy of Forester Angelito Villanueva, the SINP Superintendent, during the conduct of the field work. The cooperation of Dr. Teofanes A. Patindol, the expert who handled the fauna, is also well appreciated. 


\section{REFERENCES}

BRAUN-BLANQUET, J. 1964. Pflanzensoziologie. 3ed. Hamburg. 865p LILLO, E. G. 2004. Floristic composition of secondary forest in Argao Watershed, Cebu. MS Thesis. Leyte State University. 70p.

MACEDA, J. L. 2007. Assessment of forest resources in Patag-Gabas Watershed Forest Reserve, Baybay, Leyte. MS Thesis. Leyte State University. 74p.

MALLARI, N.A.D. 1992. Species diversity along elevational gradients in different study sites in Sierra Madre Mountaians in Isabela and Cagayan. B.S. Thesis, UP at Los Baños. 88 p.

QUIMIO, J. M 2006. Abundance status of flora in Mananga-Kotkot-Lusaran Watersheds, Cebu, Philippines. Ann. Trop. Res. 28(2):53-75.

QUIMIO, J. M. 2001. Baseline on floral diversity and pre-testing of monitoring protocol in Metro Cebu Watersheds. PCEEM. Cebu.133p.

QUIMIO, J. M. and N. L. QUILARIO. 2007. Species composition and structure of forests in Tampakan Highlands, South Cotabato, Philippines. Ann. Trop. Res. 29(2):47-65.

QUIMIO, J. M. and PATINDOL, T. A. 1999. Samar Island Biodiversity Project: Preliminary floristic inventory. DENR-R8, Tacloban City. 90p.

QUIMIO, J. M. and T. A. PATINDOL. 2012. Post-project biological resources assessment in Samar Island Natural Park. UNDP-DENR8. 180p.

SEAMEO-SEARCA. 2004. Biological resurces assessment - Samar Island Natural Park, Philippines. PAWB, DENR-8, Tacloban City. 191p.

UNDP-GEF. 2007. Samar Island Natural Park. Management Plan June 2006 -May 2016. DENR-R8, Tacloban City. 249p. 
Table 7. Vegetation table showing the frequency of occurrence of species in plots, their plot cover dominance at the tree layer, undergrowth layer and ground layer for all five transects. Percent canopy cover dominance scale: $5=75-100 \%, 4=50-75 \%$, III $=25-50 \%, B=15-25 \%, A=5-15 \%$, M $=<5 \%$, over 50 individuals, $1=<5 \%, 6-50$ individuals, $+=<5 \%, 3-5$ individuals and $\mathrm{R}=<5 \%, 1-2$ individuals. See separate table for summary of constancy levels of species. SINP, Samar Island, Philippines. 2012. This table was simplified by removing the species that occurred only in 3 or less plots. Unidentified species $=57$

\section{2}

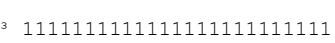


Neotrewia cumingii

Hydnocarpus subfalcata

Strombosia philippinensis

Shorea astylosa

Myristica guatteriaefolia

Hopea malibato

Hopea foxworthy
Vitex quinata

Garcinia oligophlebia

Calophyllum blanco

Memecylon sessilifolium

Croton consanguineus

Camptostemon philippinense

Myrica javanica

Syzygium crassibracteatum

Nephelium mutabile

Mimusops parviflora Gnetum gnemon

Ctenolophon philippinens

Calophyllum blancoi

Mussaenda sp

Shorea philippinensis

Chisocheton cumingianus

Myristica philippinensis

quilasia sp.

Canarium hi

Dipterocarpus grandiflorus

Timonius appendiculatus

Sapium luzonicum

Tristania micrantha

Agathis philippinensis

Glaeocarpus octopetalus

Xanthoste.n philippinensis

Diospyros bulusanensis

Xanthostemon philippi.nsis

Ormosia calavensis

Kolowratia elegans ahernia

Syzygium hutchinsonii

Evodia sessilifoliola

Vaccinium perrigidum

Tarrietia sylvatica

Cinnamomum mercadoi

Cyathocalyx apoensi
Dracontomelon edule

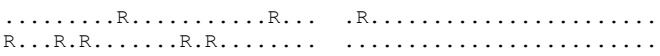

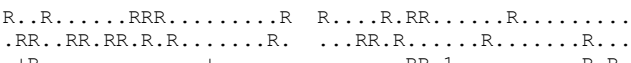

.

$\ldots \ldots \ldots \ldots R R . R \ldots R \ldots \ldots$
R.

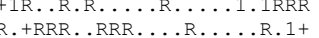
R.RRR .RR.R.R ..+++R++RRRR ....R. . ........RRRRR..R. RR.R $\ldots \ldots R \ldots R, \ldots R, \ldots$ $\ldots \ldots \ldots R \ldots \ldots \ldots \ldots+\ldots R$.

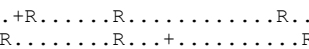

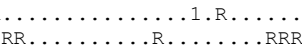

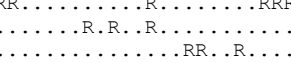

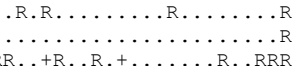
$R_{R R} .+R R_{0} R_{.}+\ldots \ldots \ldots R \ldots R R$

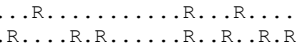
. RRRRRRR .............. ...R.R.RRR +R.R.R. .
RM.RIA1 .
RM.R.R.R

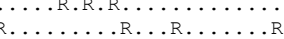
.R.R+.R.R.R.RI.R. .RRRR.R R+..R.1R1RRRR . RR ...R. R.R....R..R.....R

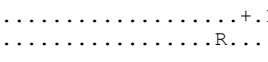


3 Trichospermum discolor Alstonia scholaris Neonauclea puberula
Pterospermum obliquu Parashorea plicata Sapium luzonicum laoxylon pubescen icania splendens Alenizia saponaria Dipterocarpus validus Sandoricum vidali Afzelia rhomboidea Litsea albayense

UNDERGROWTH LAYER

Mussaenda sp Dillenia philippinensis Myristica oblongifolia Ardisica philippinensis ncosperma tigillari Calamus ornatus Fagrea racemosa Hopea malibato

Teijsmanniodendron ahern Calophyllum blancoi Canarium hirsutum Lithocarpus llanosil Croton consanguineus Flagellaria indica

Reinwardtiodend.celebicum Artocarpus blancoi Parashorea plicata Shorea astylosa

Shorea polysper

Shorea almon Memecylon sessilifoliu Myristica laxiflora Agathis philippinensis Calliandra haematocephal Calophyllum blanco

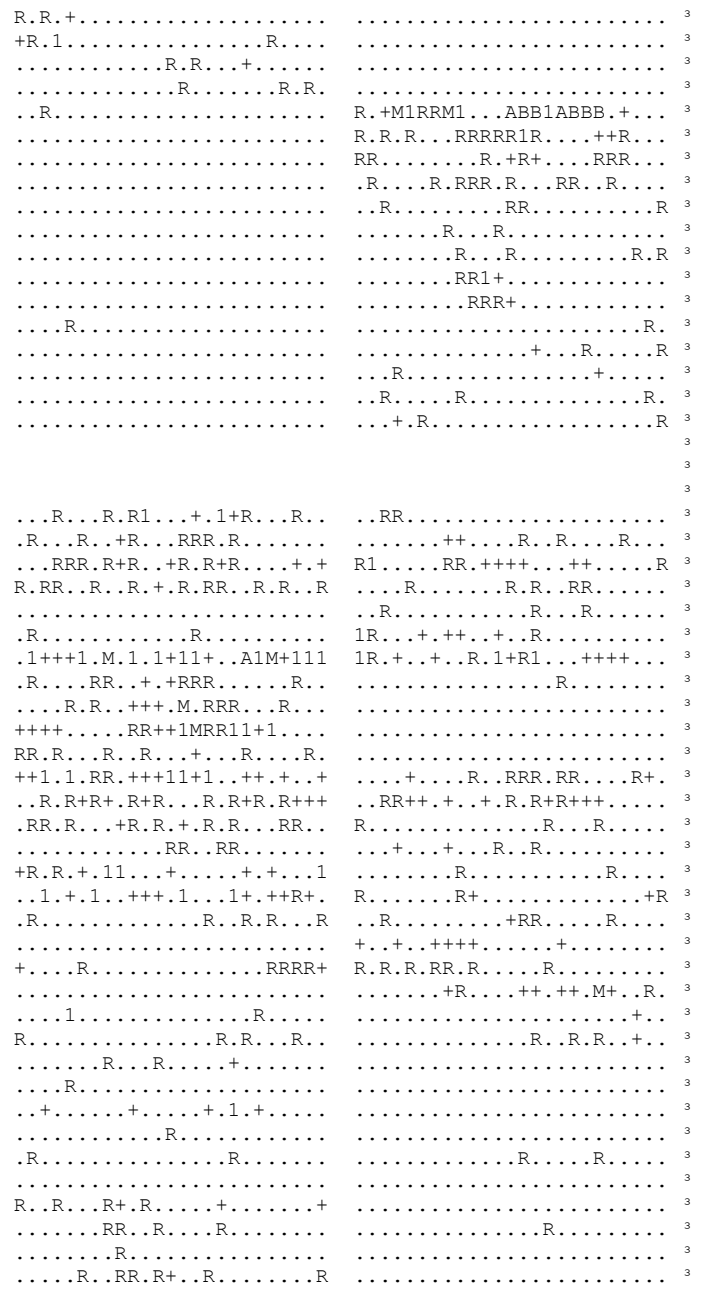


Cratoxylum celebicum Myrica javanica Dipterocarpus grandiflorus zysygium

Dipterocarpus gracilis Diospyros montana

Bumeodendron philippine Bruguiera parviflora
Dinochloa scandens Syzygium striatulu

Areca cathecu

Jossinia tulanan

Freycenetia multiflora

lalapay

Ulalapay

Syzygium garciae

Teijsmanniodend.pteropodu

Xanthostemon philippinen

Livistonia rotunalfolia

Diospyros bulusanensis

Psychotria rubiginosa

Wrightia laniti

Palaquim luzoniense

Pyzygium crassibracteatum

Cinnamomum mercadoi

Pterospermum obliquum

Vaccinium perrigidu

Homalium samarense
Podocarpus philippinensi

elastoma

Contaminan

cynometra inaeguifol

Neotrewia cumingii

Canarium calophyllum

Chisocheton cumingianus

Sapium luzonicum

areca cathecu

Musa textilis

Strombosia philippinensis

Phrynium philippinensis

roordersioden

Hydnocarpus subfalcata

Dysoxylum decandrum

Combretodend.quadrialatum

Pometia pinnata

Syzygium polycephaloides

Syzyrium asperum

R.R. . .

$R R$.

RMMMM.M1R.M1.1M1M11111111

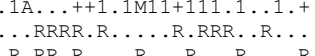

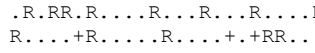

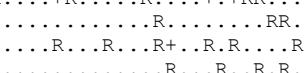

R.R.

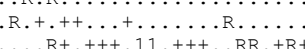
$++\mathrm{M}+++11+.11+\mathrm{M}+1++1 . \mathrm{RR} .+\mathrm{R}$ .R $\ldots \ldots \ldots \ldots \ldots . R . R \ldots$
$++1 . R 1111+11++. M 1++.++$ R....R.RR ...R . . . . . . . .
$+\ldots 1 \ldots+111 M M 11+M+. M 11+M 11$ ‥R.++..RRRR..R. R. ...R.

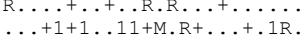

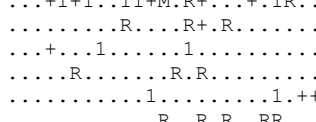
$\begin{aligned} & \ldots,+R . R \ldots \ldots R R \\ & . R+R\end{aligned} \ldots, R$ ......R. . . RR . . . . . R..R.R.RR

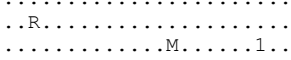

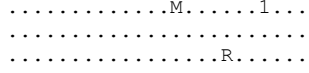

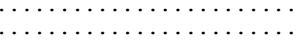
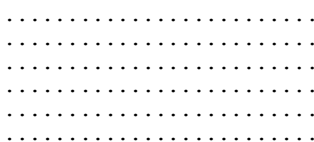


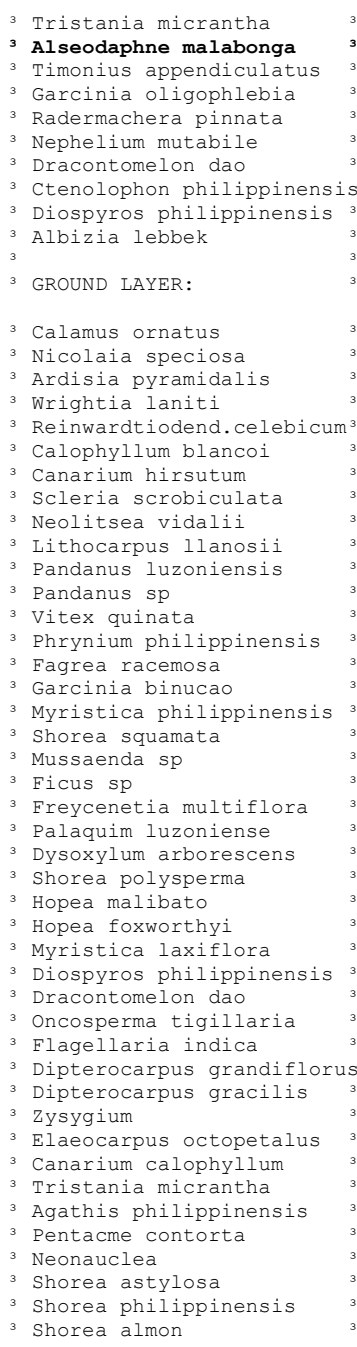

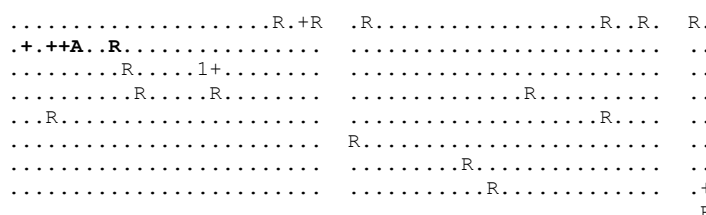

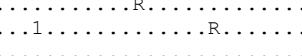

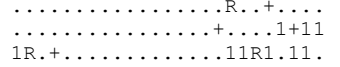

$\ldots \ldots \ldots \ldots R \ldots \ldots \ldots \ldots$
$\ldots+1 .+\ldots R, \ldots \ldots R R+R R+R$
$1 \ldots 1+\ldots R$

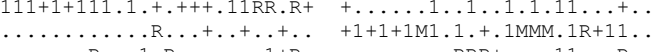

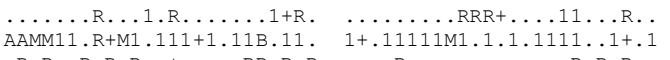

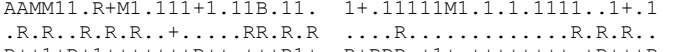

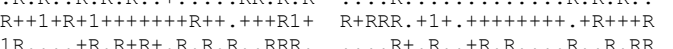
R+R+.R.R.R..RRR.

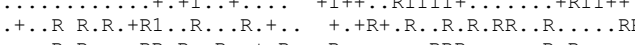

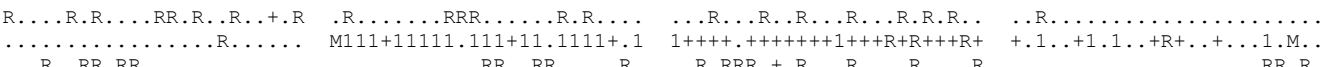

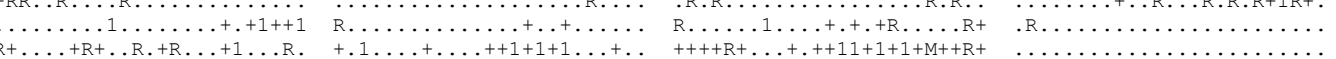

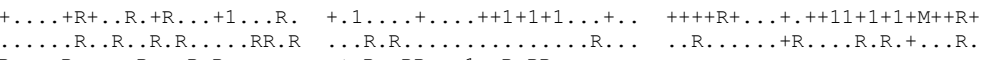

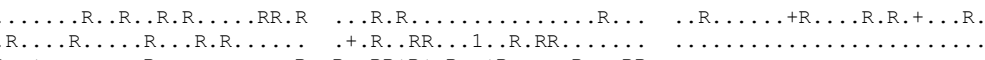

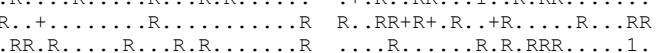

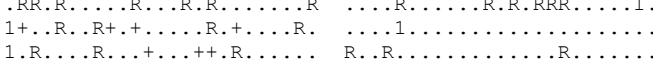
1M1MAA11.M1M+1AM1111A1+1 R.RR...R.R.R.R.R.RR.R.
I1++.+1R.MM111111M1..1.+

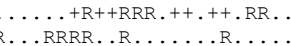


Neonauclea sp

Dillenia philippinensis

Blumeodendron philippine

Croton consanguineus

Gnetum gnemon

Cleisthanthus megacarpus

Clausena anisumolens

Cratoxylum formosum

Melastoma

Agathis philippinensis

Palaquium foxworthyi

Schizostachym diffusum

Calamus ornatus

Aseodaphne malabonga

Diospyros pilosanthera

Calophyllum lancifolium

Areca cathecu

Syzygium striatulum

Melastoma sp

Teijsmanniodendron ahernia

Dillenia philippinensis

Diospyros bulusanensis

Shorea gisok

Bruguiera parviflor

Calliandra haematocephal

Garcinia oligophlebia

Dinochloa scandens

Artocarpus blancoi

Poderpus philippinens

Nephelium mutabile

Syzygium hutchinsoni

Ficus heteropleura

Teijsmanniodend.pteropodu

Dendrocalamus merrillian

Leucaena leucoceph

Jossinia tulanan

Leucosyke capitellata

Ficus nota

Dicranopteris linearis

Urophyllum leytense

Lycodium circinatum

yathea contaminan

Bredelia pinangiana

Pterospermum obliquu

Afzella rhomboldea

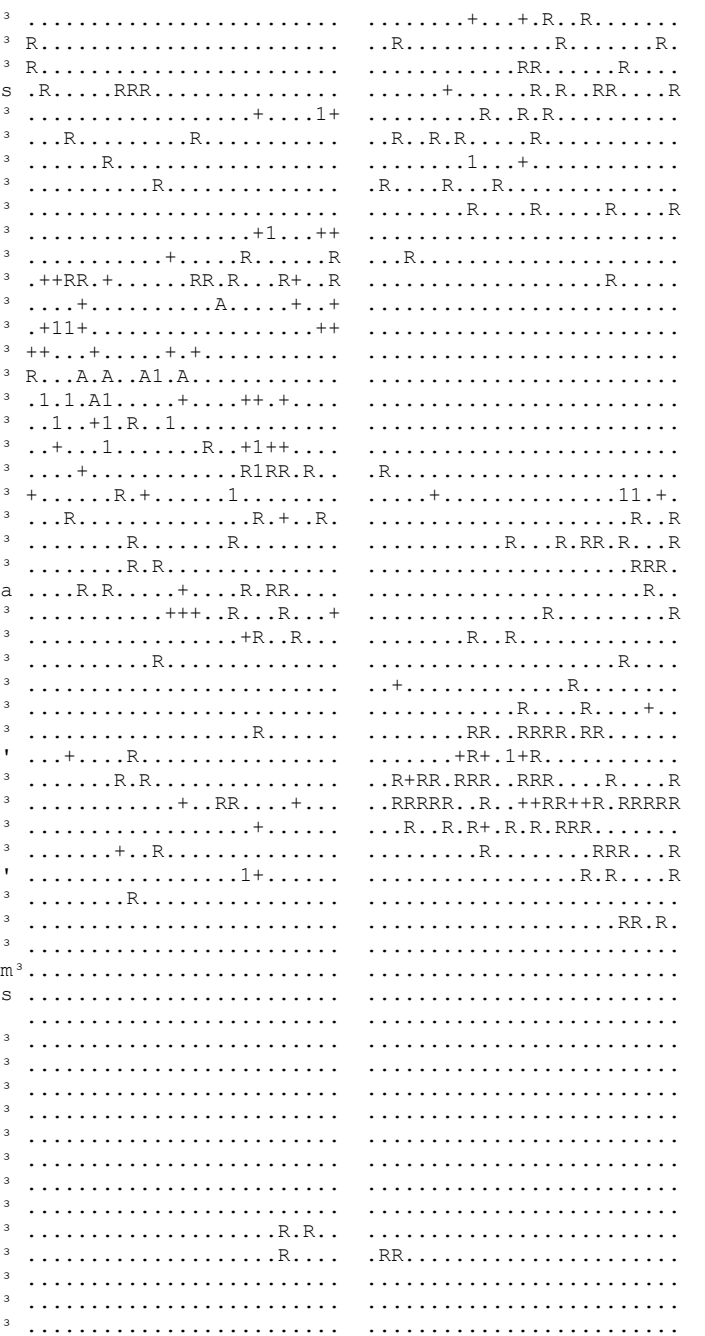

,

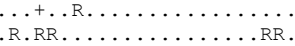

R. R.R. R .

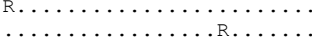

(n)

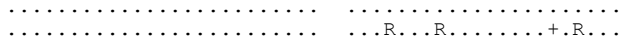

n...

R............. 
3 Syzygium crassibracteatum' Vitex turczaninowi
Dracontomelon edule 3 Vaccinium perrigidum
3 Donnax cannaeformis Donnax cannaeformis Nephelium mutabile Chisocheton pentandrus Livistonia rotundifolia Hydnocarpus subfalcata Litsea sebifera

Pseudopia cumingii Psychotria rubiginosa Pometia pinnata

Dysoxylum decandru

Toona calantas



Coniothalamus amuy

Musa textilis

Chisocheton cumingianus

Syzygium calubcob
Canthium monstruso

Canthium monstruso

Angelica flava

Cryptocarya oligocarpa

Parartocarpus venenosus

Litsea albayense

Pelantos sp

Pygeum vulgare

Semecarpus cuneiformis

Areca cathecu

Caryota cumingii

Aleurites trisperma

Diospyros parva

Symplocos villarii

Anisoptera thurifera

Dysoxylum altissimum
Terminalia foetidissima

Albizia lebbe

Xanthostemon philippinens

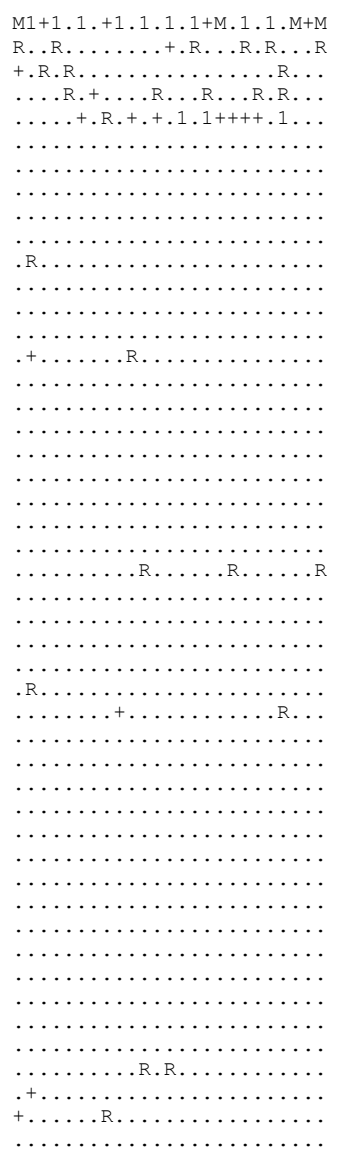

